\title{
UJI AKTIVITAS ANTIBAKTERI EKSTRAK KASAR KULIT BATANG MANGROVE Avicennia marina TERHADAP PERTUMBUHAN BAKTERI Escherichia coli
}

\section{(ANTIBACTERIAL ACTIVITY TEST OF BARK RUDE EXTRACT Avicennia marina AGAINST THE GROWTH OF BACTERIA Escherichia coli)}

\author{
Marta Ina Kii ${ }^{1}$, Andriani Rafael ${ }^{1}$, Sonya T. M. Nge ${ }^{1}$ \\ 1Program Studi Pendidikan Biologi Universitas Kristen Artha Wacana Kupang
}

Email: martainakii95@gmail.com

\begin{abstract}
ABSTRAK
Tumbuhan mangrove merupakan salah satu ekosistem pantai yang mendominasi wilayah pantai suatu daerah dan berpotensi untuk dikembangkan dalam penanggulangan berbagai penyakit baik infeksi pada ikan budidaya maupun sebagai medi pengobatan alami bagi manusia, karena senyawa metaboit sekunder yang terkandung didalamnya mampu berkhasiat sebagai antibakteri. Tujuan dari penelitian ini untuk mengetahui pengaruh ekstrak kasar kulit batang mangrove $A$. marina terhadap pertumbuhan bakteri $E$. coli dan konsentrasi optimum dari estrak kasar kulit batang mangrove A. marina dalam menghambat pertumbuhan bakteri $E$. coli. Metode yang digunakan dalam penelitian ini metode eksperimen laboratorium dengan 4 perlakuan yaitu konsentrasi $55 \mathrm{mg} / \mathrm{mL}, 60 \mathrm{mg} / \mathrm{mL}, 65$ $\mathrm{mg} / \mathrm{mL}, 70 \mathrm{mg} / \mathrm{mL}$ dan 1 kontrol tanpa pemberian ekstrak dengan 3 kali ulangan. Hasil pengamatan diameter zona hambat dianalisis secara statistik menggunakan analisis variansi (ANOVA) satu jalur dengan signifikansi $5 \%$. Analisis statistik dilakukan menggunakan program SPSS versi 16.0. Hasil penelitian menunjukkan bahwa ekstrak kasar kulit batang mangrove $A$. marina berpengaruh terhadap pertumbuhan bakteri E. coli. Hal ini dapat dilihat dar konsentrasi yang digunakan mulai dari $55 \mathrm{mg} / \mathrm{mL}$, $60 \mathrm{mg} / \mathrm{mL}, 65 \mathrm{mg} / \mathrm{mL}, 70 \mathrm{mg} / \mathrm{mL}$ memiliki rata-rata zona hambat yang berkisar antara $26 \mathrm{~mm}, 27.33$ $\mathrm{mm}, 27.66 \mathrm{~mm}$ dan $28.66 \mathrm{~mm}$. Dengan demikian semakin tinggi konsentrasi ekstrak yang digunakan, maka semakin besar daya hambat yang terbentuk.
\end{abstract}

\section{Kata Kunci : Avicennia marina, Escherichia coli, Antibakteri}

\begin{abstract}
Mangrove plant is one of the coastal ecosystems that dominates the coastal area and has the potential to be developed in the prevention of various diseases both infections in aquaculture and as a natural treatment medium for humans, because the secondary metabolite compound contained can be efficacious as an anti-bacterial. The purpose of this study was to determine the effect of $A$. marina mangrove bark extract against the growth of $E$. coli and the optimum concentration of $A$. marina mangrove bark extract in inhibiting the growth of E. coli bacteria. The method used in this study is a laboratory experimental method with 4 treatments namely a concentration of $55 \mathrm{mg} / \mathrm{mL}, 60 \mathrm{mg} / \mathrm{mL}, 65$ $\mathrm{mg} / \mathrm{mL}, 70 \mathrm{mg} / \mathrm{mL}$ and 1 control without administration of extract with 3 replications. Observation result of inhibition zone diameters were statistically analyzed using a one-way analysis was performed using the SPSS program version 16.0. the results showed that the rough extract of $A$. marina mangrove bark affected the growth of E. coli bacteria. This can be seen from the concentrations used starting from 55 $\mathrm{mg} / \mathrm{mL}, 60 \mathrm{mg} / \mathrm{mL}, 65 \mathrm{mg} / \mathrm{mL}$ and $70 \mathrm{mg} / \mathrm{mL}$ having average inhibition zones ranging from $26 \mathrm{~mm}$, $27.33 \mathrm{~mm}, 27.66 \mathrm{~mm}$ and $28.66 \mathrm{~mm}$. thus the higher the concentration of the extract used, the greatervthe inhibition formed.
\end{abstract}

Keywords : Avicennia marina, Escherichia coli, Antibacterial 


\section{PENDAHULUAN}

Tumbuhan mangrove merupakan salah satu ekosistem pantai yang mendominasi wilayah pantai suatu daerah. Mangrove merupakan tumbuhan tropis yang berpotensi untuk dikembangkan dalam penanggulangan penyakit infeksi pada ikan budidaya, karena senyawa bioaktif yang dikandungnya belum banyak digunakan sebagai orientasi ekonomi. Upaya untuk mendapatkan senyawa bioaktif dari sumber daya laut terus digalakkan, seperti pencarian senyawa bioaktif antibakterial pada spons laut (Linington dkk., 2002) dari siput bakau (Allimuddin dan Rante, 2006) telah dilakukan, namun potensi senyawa pada tumbuhan mangrove sebagai kandidat fitofarmaka budidaya perairan yang memiliki potensi farmakologisebagai antimikrobia belum banyak dikaji.

Indonesia merupakan negara dengan tumbuhan mangrove terbanyak didunia, baik segi kuantitas area $\left( \pm 42.550 \mathrm{~km}^{2}\right.$ ) maupun jumlah spesies ( \pm 202 spesies) (Spalding, 2001). Meskipun belum mewakili keragaman jenis mangrove secara keseluruhan, NTT memiliki potensi mangrove dengan keragaman jenis yang cukup tinggi yang dianalisis dari 9 lokasi yang mewakili pulau-pulau besar di NTT yaitu Flores, Sumba, Timor dan Alor terdapat sebanyak 45 jenis dan 22 famili mangrove (Hidayatullah, 2017).Selain itu, mangrove juga merupakan tumbuhan khas yang terdapat pada muara sungai dan pesisir pantai yang dipengaruhi oleh pasang surut air laut. Sebagian besar dari tumbuhan mangrove bermanfaat sebagai bahan obat (Purnobasuki, 2004). Ekstrak dan bahan mentah dari tumbuhan mangrove inilah yang telah digunakan oleh masyarakat pesisir untuk keperluan pengobatan alamiah. Senyawa aktif yang terdapat dalam tumbuhan mangrove seperti alkaloid, saponin, tannin, flavonoid dan triterpenoid dapat dimanfaatkan dalam bidang farmakologi (Wibowo dkk., 2009). Senyawa tersebut dapat digunakan sebagai racun ikan maupun antimikrobial (Kordi, 2012).

Tumbuhan $A$. marina merupakan salah satu spesies dari mangrove yang memiliki ciri khas yakni batang pohon besar dan tinggi, dominan serta hidup di muara sungai dan dekat dengan pemukiman penduduk. Tumbuhan mangrove memiliki kandungan senyawa metabolit sekunder yang berbeda-beda (Renaldi dkk., 2018), misalnya A. marina memiliki senyawa metabolit sekunder seperti fenol, flavonoid dan tannin yang diekstraksi dari kulit batang (Rafael dan Calumpong, 2018). Hasil penelitian serupa yang dilakukan oleh Darminto dkk., (2009) dan Handayani (2012) menunjukkan bahwa kulit batang Avicennia spp. mengandung senyawa metabolit sekunder berupa alkaloid, terpenoid, flavonoid dan steroid.

Bakteri merupakan mikroba prokariotik yang uniseluler dan berkembangbiak dengan cara aseksual dengan pembelahan sel. Hidup secara bebas dan parasit sebagai pathogen pada manusia dan hewan (Alimuddin, 2005). Berdasarkan pewarnaan gramnya, bakteri dapat dibedakan menjadi dua bagian yaitu bakteri gram positif dan bakteri gram negatif.Bakteri gram positif merupakan bakteri yang memiliki dinding sel yang lebih sederhana dan mengandung banyak peptidoglikan. Misalnya Microccus, Staphylococcus, Leoconoctoc, Pedioccus dan Aerococcus. Bakteri Gram negatif merupakan bakteri yang memiliki dinding sel lebih kompleks dan peptidoglikan yang lebih sedikit. Misalnya Escherichia, Citrobacter, Salmonella, Enterobacter, Vibrio, Aeromonas, Photobacterium, Chro mabacterium, Flavobacterium. Bakteri yang umum dan sering dijumpai menginfeksi manusia diantaranya yaitu Staphylococcus aureus dan Escherichia coli.

Beberapa peneliti seperti James dkk. (2002) dan Pelczar dan Chan (1986) menyatakan bahwa $S$. aureus merupakan bakteri kokus Gram positif dan patogen utama bagi manusia, mulai dari keracunan makanan maupun infeksi kulit ringan sampai infeksi berat. Bakteri $E$. coli umumnya merupakan flora normal saluran pencernaan manusia dan hewan termasuk dalam kelompok fakultatif Gram negatif yang dapat menyebabkan diare pada bayi dan orang dewasa, infeksi saluran kemih (Harti, 2015). Umumnya jika terinfeksi bakteri orang menggunakan obat-obat kimia atau antibiotik. Upaya pencarian obat yang berasal dari alam untuk mengurangi tingkat konsumsi obat kimia semakin gencar dilakukan, karena penggunaan obat kimia yang berlebihan dapat menimbulkan resistensi bakteri terhadap obat maupun antibiotik dan dapat menimbulkan tumbuhnya bakteri lain yang lebih tahan terhadap obat-obatan atau disebut juga 'super bug' (James dkk., 2002). 
Penelitian yang dilakukan oleh Bandaranayake (1998) pada mangrove jenis Rhizopora apiculata menunjukkan bahwa senyawa metabolit sekunder dapat berfungsi untuk menyembuhkan penyakit beri-beri, haematoma (kulit dan batang), hepatitis (kulit, batang, daun, bunga dan akar) dan borok (kulit dan batang). Ekstrak dari beberapa jenis tumbuhan mangrove seperti Rhizopora stylosa, Sonneratia griffithi, Aegiceras floridum dan Excoecaria agallocha memiliki daya hambat terhadap pertumbuhan $S$. aureus. Selain itu akar $R$. apiculata berpotensi dalam menghambat pertumbuhan bakteri E. coli dan S. aureus (Usman, 2017). Hasil penelitian lain yang dilakukan oleh Renaldi dkk., 2018 menunjukkan bahwa ekstrak batang, daun dan akar mangrove $A$. marina efektif dalam menghambat pertumbuhan bakteri E. coli serta penelitian serupa yang dilakukan oleh Sabiladiyni dkk., (2016) menunjukkan bahwa ekstrak daun $A$. marina efektif menghambat pertunbuhan bakteri Vibrio harveyi dan Vibrio parahaemolytics.

Desa Huilelot merupakan desa yang terletak di Kecamatan Semau Utara, Kabupaten Kupang, Provinsi Nusa Tenggara Timur. Desa ini merupakan salah satu desa yang memiliki beberapa jenis mangrove seperti Avicennia alba, Avicennia marina, Rhizophora mucronata, Rhizophora stylosa, Sonneratia alba dan Bruguiera cylindrica, tetapi penelitian yang berkaitan dengan uji aktivitas antibakteri pada jenis-jenis mangrove ini belum pernah dilakukan. Tujuan dilakukan penelitian ini adalah untuk mengetahui pengaruh ekstrak kasar kulit batang mangrove Avicennia marina (Forks.) Vierh terhadap pertumbuhan bakteri Eschrichia coli.

\section{METODE PENELITIAN}

\section{Tempat dan Waktu Penelitian}

Penelitian ini telah dilaksanakan di laboratorium Biologi, Universitas Kristen Artha Wacana (UKAW) Kupang yang berlangsung pada bulan September-Oktober 2019.

\section{Alat Dan Bahan}

Alat-alat yang digunakan dalam penelitian ini terdiri dari parang, plastik, Autoclave, Oven, timbangan analitik, lesung dan alu, beaker glass $(250 \mathrm{~mL})$, kertas saring (Whatman Nomor 42$)$, rotary evaporator, erlenmeyer $(500 \mathrm{~mL})$, aluminium foil, hotplate, tabung dan rak tabung reaksi, kapas steril, vortex, jarum ose, Bunsen, jarum ose, batang L, pipet tetes, pinset, Inkubator, penggaris, alat tulis, kamera digital. Bahan-bahan yang digunakan diantaranya sampel kulit batang tumbuhan $A$. marina yang diambil dari Desa Huilelot, Kecamatan Semau, Kabupaten Kupang. Media NA, bakteri E. coli yang diambil dari laboratorium Biologi UKAW, pelarut metanol, aquades dan alkohol.

\section{Prosedur Penelitian \\ Penanganan Sampel}

Kulit batang mangrove $A$. marina dicuci dengan air bersih lalu dipotong-potong dan dikeringanginkan selama 2 minggu, lalu sampel dihaluskan dengan cara dipotong-potong dan ditumbuk kemudian disaring sampai mendapatkan serbuk. Sampel yang telah halus disimpan pada suhu ruangan untuk tindakan selanjutnya (Renaldi dkk., 2015).

\section{Sterilisasi Alat}

Sterilisasi alat dilakukan sebelum peralatan digunakan yaitu dengan cara membungkus peralatan (cawan petri) tersebut menggunakan kertas, kemudian dimasukkan ke dalam oven pada suhu $121^{\circ} \mathrm{C}$ selama 15 menit. Sedangkan alat yang tidak tahan panas disterilisasi menggunakan zat kimia berupa alkohol $70 \%$.

\section{Maserasi dan Ekstraksi}

Sebanyak 50 gram sampel kulit batang tumbuhanmangrove $A$. marina yang telah halus diekstraksi dengan pelarut methanol $(\mathrm{b} / \mathrm{v} ; 1 / 4)$ dan difiltrasi. Residu yang diperoleh kemudian diekstraksi kembali dengan pelarut yang sama sampai semua senyawa terangkat. Kemudian sampel disaring menggunakan kertas saring (Whatman Nomor 42) dan diuapkan menggunakan Rotary Evaporator sehingga diperoleh ekstrak pekat. Ekstrak kasar yang diperoleh disimpan dalam botol sampel untuk dilakukan uji lanjut (Britton dkk., 1995).

\section{Pembuatan Medium Agar (NA)}


Indigenous Biologi

Jurnal pendidikan dan Sains Biologi

3(2) 2020

Pembuatan media dilakukan dengan cara menyiapkan erlenmeyer dan melarutkan 6 gr media NA kedalam $300 \mathrm{~mL}$ aquades, tutup menggunakan alumunium foil lalu media dipanaskan menggunakan hot plate with magnetic stirer sampai homogen. Untuk pembuatan agar miring masukkan NA kedalam 5 tabung reaksi dengan takaran masingmasing sebanyak $5 \mathrm{~mL}$ kemudian ditutup dengan kapas. Setelah disterilisasi tabung segera dimiringkan pada rak tabung sampai dingin. Untuk pembuatan medium NA setelah dilakukan sterilisasi, media agar dalam erlenmeyer kemudian secara aseptik dituang kedalam cawan petri dengan masing-masing cawan petri $15 \mathrm{ml}$ dan diamkan pada suhu ruang (Yunus dkk., 2018).

\section{Uji Antibakteri}

Setelah mendapat biakan murni bakteri E. coli, ambil bakteri tersebut dari agar miring dan dimasukkan dalam tabung reaksi yang berisikan aquadest dengan menggunakan jarum ose untuk dilakukan pengenceran yaitu dengan cara ambil $1 \mathrm{~mL}$ kultur dan ditambahkan kedalam $9 \mathrm{~mL}$ aquades dan dilakukan pengenceran $10^{-1}$ kemudian divortex. Hasil pengenceran $10^{-1}$ dipindahkan $1 \mathrm{~mL}$ ke tabung $10^{-2}$ dan di vortex, kemudian dipindahkan ke tabung $10^{-3}$ dan selanjutnya dipindahkan ke tabung $10^{-4}$. Setelah divortex hasil pengenceran $10^{-4}$ dipindahkan ke cawan petri (agar plate) menggunakan mikropipet dengan metode spread plate.

Kemudian encerkan ekstrak kasar kulit batang $A$. marinasesuai dengan konsentrasi yang telah ditentukan yaitu $55 \mathrm{mg} / \mathrm{mL}, 60 \mathrm{mg} / \mathrm{mL}, 65 \mathrm{mg} / \mathrm{mL}$ dan $70 \mathrm{mg} / \mathrm{mL}$. Kemudian direndam kertas cakram ( $6 \mathrm{~mm}$ ) selama 15 menit. Selanjutnya, meletakkan kertas cakram tersebut dengan mengunakan pinset diatas inokulum bakteri dalam cawan petri. Setelah itu diinkubasi pada suhu $37^{\circ} \mathrm{C}$ selama 24 jam. Selanjutnya pengukuran zona hambat yang terbentuk digunakan penggaris dengan cara membalik cawan petri. Aktivitas antibakteri dinyatakan positif apabila terbentuk zona hambat berupa zona bening disekeliling kertas cakram (Liwang dkk., 2013). Data hasil pengamatan dianalisis secara statistik menggunakan analisis variansi ANOVA satu jalur dengan taraf signifikansi $5 \%$. Analisis statistik dilakukan dengan menggunakan program SPSS versi 16.0.

\section{HASIL DAN PEMBAHASAN}

Hasil uji aktivitas antibakteri ekstrak kasar kulit batang mangrove jenis $A$. marina terhadap pertumbuhan bakteri $E$. coli menggunakan variasi konsentrasi $55 \mathrm{mg} / \mathrm{mL}, 60 \mathrm{mg} / \mathrm{mL}, 65$ $\mathrm{mg} / \mathrm{mL}, 70 \mathrm{mg} / \mathrm{mL}$ dan kontrol sebagai pembanding. Cawan petri yang telah diinkubasi selama 24 jam pada suhu $37^{\circ} \mathrm{C}$ kemudian dilihat zona hambat yang terbentuk. Zona hambat yang terbentuk dalam penelitian ini dapat dilihat pada gambar 1 .

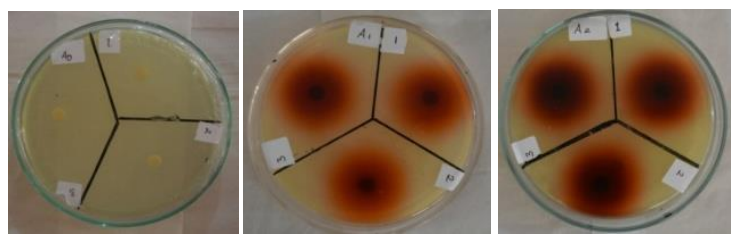

(a) (b)

(c)

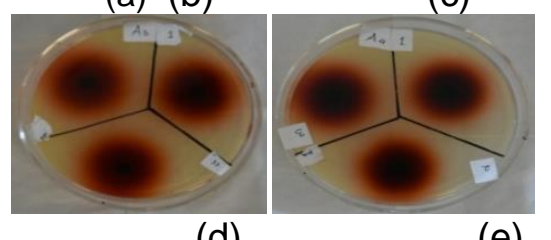

Gambar 1. Diameter Zona Bening Pada Setiap Konsentrasi; a) Kontrol $0 \mathrm{mg} / \mathrm{mL}$, b) Konsentrasi (55 mg/mL), c) Konsentrasi $(60 \mathrm{mg} / \mathrm{mL})$,d) Konsentrasi $(65 \mathrm{mg} / \mathrm{mL})$, e) Konsentrasi $(70 \mathrm{mg} / \mathrm{mL})$ 
Pengamatan terhadap pertumbuhan bakteri dilakukan setelah diinkubasi selama 24 jam dan dilakukan pengukuran. Hasil pengukuran diameter zona hambat bakteri $E$. coli dengan variasi konsentrasi ekstrak kasar kulit batang mangrove $A$. marina dapat dilihat pada Tabel 1 .

Tabel 1 Diameter zona hambat setiap perlakuan

\begin{tabular}{ccccccc}
\hline Perlakuan & $\begin{array}{c}\text { Konsentrasi Ekstrak } \\
\text { Kulit Batang } A . \\
\text { marina }(\mathrm{mg} / \mathrm{mL})\end{array}$ & \multicolumn{2}{c}{$\begin{array}{c}\text { Diameter Zona } \\
\text { Hambat }(\mathrm{mm})\end{array}$} & \multirow{2}{*}{$\begin{array}{c}\text { Rata- } \\
\text { rata } \\
(\mathrm{mm})\end{array}$} & $\begin{array}{c}\text { Kategori zona } \\
\text { hambat }(\mathrm{mm})\end{array}$ \\
\cline { 3 - 5 } A0 & 0 & U1 & U2 & U3 & & \\
\hline A1 & 55 & 24 & 25 & 29 & 26 & Sangat kuat \\
\hline A2 & 60 & 29 & 24 & 29 & 27.33 & Sangat kuat \\
\hline A3 & 65 & 29 & 25 & 29 & 27.66 & Sangat kuat \\
\hline A4 & 70 & 30 & 27 & 29 & 28.66 & Sangat kuat \\
\hline
\end{tabular}

Keterangan : A0: Perlakuan ke-1, A1: Perlakuan Ke-2, A2: Perlakuan Ke-2, A3: Perlakuan Ke3, A4: Perlakuan Ke-4, U1: Ulangan Ke-1, U2: Ulangan Ke-2, U3: Ulangan Ke-3

Tabel 1 menunjukkan hasil pengukuran diameter zona hambat terhadap pertumbuhan bakteri $E$. coli. Zona hambat yang terbentuk dengan pemberian konsentrasi ekstrak kasar kulit batang $A$. marina yang berbeda-beda. Penambahan ekstrak pada semua variasi konsentrasi memiliki pengaruh dalam menghambat pertumbuhan bakteri $E$. coli dan dikategorikan sebagai daya hambat sangat kuat.

Pemberian ekstrak kasar kulit batang $A$. marina memiliki pengaruh terhadap pertumbuhan bakteri $E$. coli.Hal ini dapat dilihat dari konsentrasi yang digunakan mulai dari $55 \mathrm{mg} / \mathrm{mL}, 60 \mathrm{mg} / \mathrm{mL}, 65 \mathrm{mg} / \mathrm{mL}$ dan $70 \mathrm{mg} / \mathrm{mL}$ memiliki rata-rata zona hambat yang berkisar antara $26 \mathrm{~mm}$ sampai dengan $28.66 \mathrm{~mm}$. Penelitian yang dilakukan oleh Ernawati dan Hasmila (2014) yang menggunakan ekstrak daun $R$. mucronatamemperlihatkan daya hambat sebesar 13,42 mm dengan kategori kuat pada konsentrasi tertinggi $60 \%$. Semakin tinggi konsentrasi yang digunakan maka semakin besar diameter zona hambat yang terbentuk.

Hasil penelitian ini didukung oleh penelitian yang dilakukan oleh Paputungan dkk., (2017) yang menemukan bahwa senyawa metabolit sekunder yang terdapat pada ekstrak buah $S$. albaseperti tannin berfungsi sebagai antibakteri dan antioksidan sedangkan fenol dan flavonoid berfungsi sebagai antioksidan. Penelitian yang dilakukan oleh Muda (2019) menggunakan ekstrak kulit batang $A$. marina menunjukkan hasil positif adanya senyawa metabolit sekunder seperti fenol, flavonoid dan tanninmerupakan salah satu faktor yang mempengaruhi luasarea daya hambat bakteri yang terbentuk.Penelitian yang dilakukan oleh Ernawati dan Hasmila (2014) menunjukkan bahwa pada konsentrasi $40 \%$ ekstrak daun mangrove $R$. mucronata sudah mampu menghambat pertumbuhan bakteri $E$. coli dengan kategori sedang. Dengan demikian penggunaan konsentrasi yang semakin tinggi dapat menghambat pertumbuhan bakteri.

Penelitian serupa yang dilakukan oleh Renaldi dkk.(2018) dengan menggunakan kulit batang, daun dan akar dari $A$. marina berpengaruh terhadap pertumbuhan bakteri $E$. coli. Hal ini diduga karena ekstrak batang mangrove $A$. marina memiliki senyawa antimikroba seperti steroid dan triterpenoid. Selain itu senyawa streroid dan triterpenoid juga ditemukan pada bunga dan buah A.marina (Zhu dkk., 2009; Ravikumar dkk., 2010; Yusuf., 2010; Kiplimo dkk., 2011; Doughari 2012).

Konsentrasi ekstrak kulit batang $A$. marina yang digunakan menyebabkan dinding sel bakteri menjadi rusak sehingga pertumbuhan bakteri menjadi terhambat. Pada penelitian ini bakteri yang digunakan merupakan bakteri yang termasuk dalam bakteri gram negatif yang mengandung banyak lipid, sedikit peptidoglikan, membranuar berupa bilayer yang berfungsi sebagai pertahanan selektif senyawa-senyawa yang keluar atau masuk sel dan menyebabkan efek toksik (Pradana dkk., 2014). 


\section{Indigenous Biologi}

Jurnal pendidikan dan Sains Biologi

3(2) 2020

Menurut Jawetz dkk. (2001) pertumbuhan bakteri yang terhambat atau kematian bakteri akibat suatu zat antibakteri dapat disebabkan oleh penghambatan terhadap fungsi membran sel, penghambatan terhadap sintesis protein atau penghambatan terhadap sintesis asam nukleat. Mekanisme penghambatan yang mungkin terjadi pada bakteri $E$. coli adalah penghambatan sintesis dinding sel yang didasarkan pada adanya kandungan flavonoid yang merupakan senyawa fenol (Harbone, 1987).

\section{KESIMPULAN}

Berdasarkan hasil penelitian dapat disimpulkan bahwa ekstrak kasar kulit batang $A$. marina berpengaruh terhadap pertumbuhan bakteri $E$. coli. Semakin tinggi konsentrasi ekstrak yang digunakan, maka semakin besar daya hambat bakteri yang terbentuk.

\section{SARAN}

1. Perlu dilakukan penelitian lanjutan mengenai uji aktivitas antibakteri dari ekstrak kasar kulit batang $A$. marina terhadap bakteri lain maupun jamur dengan konsentrasi dan metode yang berbeda.

2. Perlu dilakukan penelitian lanjutan mengenai manfaat lain dari kulit batang mangrove $A$. marina selain sebagai antibakteri misalnya sebagai pewarna alami kain.

\section{DAFTAR PUSTAKA}

Alimuddin, A. 2005. Mikrobiologi Dasar Jilid 1. Cetakan 1; Makassar; UNM Press.

Alimuddin, A.,\& Rante H. 2006. Uji Toksisitas Ekstrak Daging Siput Bakau Terhadap Artemia salina Leach. Jurnal Farmasi dan Farmakologi. Vol. 10 No 1.

Bandaranayake, W. M. 1998. Traditional and medical uses of mangroves. Mangroves and Salt Marshes 2:133-148

Britton, G., S. L. Jansen, and H. Pfander. 1995. Carotenoids Volume 1A: Isolationand Analysis. Birkhauser Verlag. Basel Boston Berlin. pp: 81-107

Darminto, A. Ali, I. Dini. 2009. Identifikasi Senyawa Metabolit Sekunder Potensial Menghamba $t$ Pertumbuhan Bakteri Aeromonas hydrophila dariKulit Batang Tumbuhan Avicennia sp. Chemical. 10 (2): 92-99.

Doughari, J. H. 2012. Fitokimia- Perspektif Global Tentang Peran Mereka Dalam Nutrisi dan Kesehatan. Fitokimia: Metode Ekstraksi Struktur Dasar dan Cara Tindakan Sebagai Agen Kemoterapi Potensial. 1-32

Ernawati dan Hasmila I. 2014. Uji Fitokimia dan Uji Aktivitas Antibakteri Senyawa Metabolit S ekunder

Ekstrak

Methanol Daun Mangrove (Rhizopora mucronata). FMIPA. Universitas Negeri Makassar

Harbone, J. B. 1987."Metode fitokimia, Terjemahan K."Padmawinata dan I. Soediso, Penerbit ITB, Bandung

Harti, A. S. 2015. Mikrobiologi Kesehatan.

Hidayatullah M.2017. Mangroves Nusa Tenggara Timur : Kaya Ragam Jenis Tetapi Miskin Pemanfaatannya. Peneliti Balai Penelitian Dan Pengembangan Teknologi Hasil Hutan. Lombok barat- NTB

James J, Baker C, Swain H. 2002. Prinsip-prinsip Sains untuk Keperawatan. Diterjemahkan Oleh Indah RetnoWardhani. Jakarta:Penerbit Erlangga.

Jawetz. 2005. Mikrobiologi Kedokteran. Salemba Medika. Jakarta

Kiplimo J J; Koorbanally N A; Chenia H. 2011. Triterpenoids from vernoia auriculifera Hiern exhibit antimicrobial activity. African journal Of Pharmacy and Pharmacology 5 (8): 11501156

Kordi GH. Ekosistem mangrove: Potensi, Fungsi dan Pengelolaan. Jakarta: Penerbit Rineka Cipta.

Linington, R.G., Roberstson, M. G., Gauthier, A., Finlay, B. B., Soest, R., Anderson, R.J. 2002. Caminoside, An Antimicrobial Glicolipid Isolated From The Marine Sponges Caminus spaeroconia. 14 Nov: 4 (23). 4089-4092. 
Liwang F; Bara R; Awaloei; Wuisan J. 2013. Uji Aktivitas Antibakteri JamurEndofit Akar Bakau Avicennia marina terhadap bakteri S. aureus dan E. coli. Fakultas Kedokteran Universitas Sam Ratulangi Manado

Muda, E.Y. 2019.Screening Senyawa Metabolit Sekunder Pada Kulit Batang Tumbuhan Avicennia marina (Forks.) Vierh dan Sonneratia alba J. Smith di desa Huilelot, Kecamatan Semau, Kabupaten Kupang. Universitas Kristen Artha Wacana. Kupang-NTT

Paputungan, Zulkifli; Wonggo, Djuhria; Kaseger, Bertie Elias. 2017. Uji Fitokimia dan Aktivitas Antioksidan Buah Mangrove Sonneratia Alba Di Desa Nunuk Kecamatan Pinolosian Kabupaten Bolaang Mongondow Selatan Sulawesi Utara.Media Teknologi Hasil Perikanan. 5.3: 96-102.

Pelczar M J, Chan ECS. 1986. Dasar-dasar mikrobiologi. Vol ke-1, 2. Hadioetomo RS, Imas T, Tjitrosomo S, Angka SI, Penerjemah; Jakarta : UI Press. Terjemahan dari Elements Of Mirobiology.

Pradana, D., D. Suryanto, Y. Djayus. 2014. Uji Daya Hambat Ekstrak Kulit Batang Rhizopora mucronata Terhadap Pertumbuhan Bakteri Aeromonas hydrophila, Streptococcus agalactiae Dan Jamur Saprolegnia sp. Secara Invitro. Jurnal Aquacoastmarine. 2(1):78

Purnobasuki H. 2004. Potensi Mangrove Sebagai TanamanObat. Surabaya: UNAIR

Rafael, A and Hilconida P. Calumpong. 2014. Comparison Of Litter Production Between Natural And Reforested Mangrove Areas In Central Philippines."Aquaculture, Aquarium, Conservation and Legislation.

Ravikumar S; Gnanadesigan M; Suganti P; Ramalakshmi A. 2010. Antibacterial Potential Of Chosen Mangrove Plants Againts Isolated Urinary Tract Infectious Bacterial Pathogens. International Journal Of Medicine And Medical Science2 (3): 94-99

Renaldi, Rozirwan Dan T Zia Ulqodry. 2018. Bioaktivitas senyawa bioaktif pada mangrove $A$. marina dan B. Gymnorrhiza sebagai antibakteri yang diambil dari pulau Payung dan Tanjung api-api. Maspari Jurnal 10(1): 73-80. Program Studi Ilmu Kelautan. Indralaya

Sabiladiyni, H A, Bahri M.S; Feska S ;dian R trianto A. 2016. Ekstrak Daun Mangrove (Avicennia marina) Sebagai Bahan Antibakteri Untuk Penanggulangan Bakteri Pathogen Pada Budidaya Udang Windu.Prossiding Seminar Nasional Tahunan Ke-, Hasil Penelitian Perikanan Dan Kelautan. Program Studi IImu Kelautan, Fakultas Perikanan Dan IImu Kelautan. Semarang

Spalding, M. D., C. Ravilious and E.P. Green. 2001. World Atlas of Coral Reefs. University of California Press. Berkeley. USA.

Usman. 2017. Uji Fitokimia Dan Uji Antibakteri Dari Akar R. Apiculata Terhadap Bakteri E. coli dan S. aureus. Jurnal kimia dan Pendidikan 2(3): 169-177. Program Studi Pendidikan Kimia Universitas Sebelas Maret. Samarinda

Wibowo, Cahyo., C. Kusmana, A. Suryani, Y. Hartati dan P. Oktadiyani. 2009. Pemanfaatan Jenis Pohon Mangrove Api-Api (Avicennia spp.) Sebagai Bahan Pangan dan Obat-obatan. Seminar Hasil Penelitian. Institut Pertanian Bogor: Bogor.

Yunus, M.F., Nge, S.T.,\& Sabuna, Ch.A. 2018. Uji Aktivitas Antibakteri Ekstrak Kulit Buah Del ima Merah (Punica Granatum L.) Terhadap Pertumbuha Vibrio Cholera. Indigenous Biologi : Jurnal Pendidikan dan Sains Biologi 1(3): 10-16.

Yusuf S. 2010. Isolasi dan Penentuan Struktur Molekul Senyawa Triterpenoid dari Kulit Batang Kayu api-api Betina (Avicennia marina Neesh). Jurnal Penelitian Sains 13 (2): 23-27

Zhu F; Chen X; Yuan Y; Huang M;Sun H; Xiang W. 2009. The chemical investigation of the mangrove plant Avicennia marina and its endophytes. The Open Natural Product Journal 2:24-32 